\title{
Antioxidant activity of Galium mollugo L. extracts obtained by different recovery techniques
}

\author{
Petar S. Milić ${ }^{1}$, Ljiljana P. Stanojevići ${ }^{2}$ Katarina M. Rajković ${ }^{1}$, Slavica M. Milić ${ }^{3}$, Vesna D. Nikolić2 \\ Ljubiša B. Nikolić ${ }^{2}$, Vlada B. Veljković ${ }^{2}$ \\ ${ }^{1}$ High Chemical and Technological School for Professional Studies, Kruševac, Serbia \\ ${ }^{2}$ University of Niš, Faculty of Technology, Leskovac, Serbia \\ ${ }^{3}$ Pharmacy "Sveti Nikola", Leskovac, Serbia
}

\begin{abstract}
The yield of extractive substances, antioxidant activity, as well as total phenolic and total flavonoid contents of aqueous-ethanolic extracts obtained from aerial parts of Galium mollugo L. by different extraction techniques (maceration, reflux and ultrasonic extraction) are reported. The antioxidant activity of extracts was tested by measuring their ability to scavenge a stable DPPH free radical, while the total phenolic and total flavonoid contents were determined according to the Folin-Ciocalteu procedure and a colorimetric method, respectively. The Duncan's multiple range tests were used to evaluate if there were significant differences among yields of extractive substances, total phenolics, total flavonoids and $E C_{50}$ values for the extracts obtained by different extraction techniques. The extracts obtained by the reflux extraction contained higher amounts of extractive substances, as well as phenolic and flavonoid compounds, and showed a better antioxidant activity than those obtained by the two other recovering techniques.
\end{abstract}

Keywords: antioxidant activity, Duncan's multiple range test, extraction technique, Galium mollugo L., total phenolics content, total flavonoids content.

SCIENTIFIC PAPER

UDC 66.061.3:58:615.89

Hem. Ind. 67 (1) 89-94 (2013)

doi: 10.2298/HEMIND120314042M

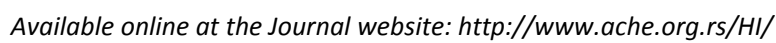

Due to an ever increasing number of malignant, cardio-vascular diseases and infections, in recent times, the attention is drawn to plants with antioxidative activity. These disorders are considered to be provoked, in most cases, by harmful effects of free radicals [1,2]. Antioxidants can be natural or synthetic compounds with an ability to scavenge free radicals and prevent oxidation [2]. Antioxidants stabilize substances inclined to oxidation, i.e., they impede the new degradation. Antioxidative properties of various spicy herbs have been long known, and they were used as food supplement not only to improve the flavor but also to preserve the food quality [3]. A great number of natural antioxidants occur, the most important among them being vitamins such as $\alpha$-tocopherol [4], ascorbic acid $[5,6]$, retinol, thiamin and riboflavin, flavonoids [7], and phenolic acids [4]. Synthetic antioxidants, which are claimed to stimulate the development of cancer in human tissues [8], are replaced by active natural antioxidants, and many researchers have aimed towards studies of antioxidant activity of different plant materials [9].

It is well known that many plants are an excellent renewable resource of natural antioxidants such as the

Correspondence: Lj. Stanojević, University of Niš, Faculty of Technology, Bulevar oslobođenja 124, 16000 Leskovac, Serbia.

E-mail: ljiljas76@yahoo.com

Paper received: 14 March, 2012

Paper accepted: 23 April, 2012 genus Galium with 37 species [10]. The aerial parts of a perennial herb from this genus, lady's bedstraw ( $G a-$ lium) are collected during dry and sunny days of the blooming period, to be used as a drug. In the traditional medicine, lady's bedstraw is used as a diuretic, sedative or spasmolytic, as well as for the treatment of skin and rheumatic diseases [11]. Yellow lady's bedstraw ( $G a-$ lium verum) has been studied both chemically and pharmacologically $[12,13]$, while there is little data on white lady's bedstraw (Galium mollugo). Yellow lady's bedstraw (Galium verum) contains essential oils [14], phenols [15], flavonoids [10,15], as well as various types of anthraquinone $[16,17]$. The antioxidative activity of yellow bedstraw extracts has been proven by Lakić et al. [10]. The white lady's bedstraw contains flavonoids, but their yield is three times less than that of yellow lady's bedstraw [15].

The available research works present no data on the influence of different extraction techniques on the yield of extractive substances from the aerial parts of white lady's bedstraw. Furthermore, there is no comparative study of antioxidant activity of its extracts obtained by different extraction techniques.

Ultrasonic extraction has been widely used for recovering bioactive substances from different parts of a number of medicinal herbs [18]. The effect of ultrasound on the kinetics and the yield of extractive substances from the plant material is hard to predict because it depends on many factors such as the nature of 
plant material and the bioactive substances, system phases, solvomodule, type of ultrasonic extractor, the power and frequency of ultrasound, and so on [19-21]. Ultrasound usually increases the extraction yield at lower temperatures in shorter times, and therefore, ultrasonic extraction is faster than the traditional techniques, such as maceration and Soxhlet extraction [22$-24]$.

In the present work, the extraction of extractive substances from the aerial parts of $G$. mollugo by ultrasonic and classical solvent extractions (maceration and reflux extraction) using an aqueous ethanol solution ( $50 \%$ vol.) as the extracting solvent was studied. The aim of this work was to compare the yields of extractive substances, as well as total phenolic and flavonoid componds in the extracts obtained by different extraction techniques. Additionally, the antioxidant activity of the extracts obtained by different extraction techniques were compared. Potentials of the aqueous ethanolic G. mollugo extracts for practical uses have not been previously studied in detail, so this work provides important data about the natural antioxidants present in the aerial parts of $G$. mollugo.

\section{EXPERIMENTAL}

\section{Plant material}

The aerial parts of white lady's bedstraw (Galium mollugo) were collected during the blooming season of the plant at the foot of the mountain Kruševica, south Serbia. The plant material was dried at the room temperature and ground by a mill (Alpina) immediately before the extraction. The mean particle diameter $(0.75 \mathrm{~mm})$ of the grounded plant material was determined by the sieve analysis.

\section{Chemicals and reagents}

The Folin-Ciocalteu reagent, 2,2-diphenyl-1-picrylhydrazil (DPPH), gallic acid and rutin were obtained from Sigma (St. Louis, USA). Sodium carbonate, potassium acetate and aluminum chloride hexahydrate were purchased from Merck-Alkaloid (Skopje, FYR Macedonia). All other chemicals were of analytical reagent grade.

\section{Extraction techniques}

\section{Maceration}

The grounded plant material $(7.5 \mathrm{~g})$ and the aqueous ethanol solution (50 vol.\%; $150 \mathrm{ml}$ ) were put in Erlenmeyer flasks, which were then placed in a thermostatted water bath. The extraction was performed at 25 ${ }^{\circ} \mathrm{C}$ in $24 \mathrm{~h}$. At the end of the extraction, the liquid extract was separated from the solid residue by vacuum filtration. The solvent was evaporated in a rotary vacuum evaporator at $40{ }^{\circ} \mathrm{C}$ to constant weight of dry extract. The obtained extracts were stored in a freeze for subsequent analysis.

\section{Reflux extraction}

Grounded plant material ( $7.5 \mathrm{~g}$ ) was extracted with the aqueous ethanol solution ( $50 \%$ vol.; $150 \mathrm{ml}$ ) by the maceration under reflux. The reflux extraction was carried out at the boiling temperature for $\mathbf{2 4 0}$ minutes. Dry extract was obtained using the same procedure as described in the previous section.

\section{Ultrasonic extraction}

Grounded plant material (7.5 g) was extracted with aqueous ethanol solution ( $50 \mathrm{vol} . \% ; 150 \mathrm{ml}$ ) in the presence of low-frequency ultrasound. Sonication was performed for 90 min using an ultrasonic cleaning bath (Sonic, Niš, Serbia; internal dimensions: $30 \times 15 \times 20 \mathrm{~cm}$; total nominal power: $3 \times 50 \mathrm{~W}$; and frequency: $40 \mathrm{kHz}$ ). The temperature was maintained at $25{ }^{\circ} \mathrm{C}$. At the end of the extraction process, the liquid extract was separated from the solid residue by vacuum filtration. Dry extract was obtained using the same procedure as described in the previous sections.

\section{Extractive substances yield}

The yield of extractive substances (dry extract) was calculated from the mass of the dry extract after the solvent evaporation and the mass of the original plant material, \% (w/w).

\section{Analytical methods \\ DPPH assay}

The capacity of extracts to scavenge free DPPH radicals was determined by the DPPH test $[25,26]$, according to the procedure described in details elsewhere $[27,28]$.

\section{Total phenolics content}

The total phenolics content in the extracts was determined spectrophotometrically according to the Folin-Ciocalteu method [29] using gallic acid as a standard.

\section{Total flavonoids content}

The total flavonoids content was determined according to the aluminum chloride colorimetric method [30]. The procedure described in details can be found elsewhere [28].

\section{Statistical analysis}

Results are expressed as the mean $\pm S D$ of three independent experiments. Duncan's multiple range test was used to evaluate if there were significant differences among yields of extractive substances, total phenolics, total flavonoids and $E C_{50}$ value for extracts obtained by maceration, reflux and ultrasonic extraction. The values that have no common superscript are 
significantly different according to Duncan's multiple range test. The level of confidence used in the statistical analysis of the data was $95 \%$.

\section{RESULTS AND DISCUSSION}

\section{Yield of extractive substances}

The yields of extractive substances obtained by the maceration, reflux and ultrasonic extraction of G. mollugo aerial parts are given in Table 1 . It seemed that the extractive substance yield depended on the extraction technique. However, according to the results of Duncan's multiple range test at the $95 \%$ significance level, the yield of extractive substances achieved by the reflux extraction was only significantly higher by approximately $5 \%$ than that obtained by the maceration, which was attributed to the higher extraction temperature. Compared to the silent maceration, sonication did not increase the yield of extractive substances at the $95 \%$ significance level, but ultrasound reduced greatly the time duration of the extraction process (1.5 $\mathrm{h}$ for ultrasonic extraction versus 4 hours for reflux extraction and $24 \mathrm{~h}$ for maceration). Previously, it was found that there was no significant increase in the extraction yield for prolonged extraction times than those applied. The reduction of time duration under sonication could be attributed to disruption of cell walls, particle size reduction and enhanced mass transfer of the cell content via cavitation bubble collapse $[18,19,31]$. There was no statistically significant difference at the significance level of $95 \%$ between the yields of extractive substances achieved by the reflux and ultrasonic extraction, which was attributed to the increase of temperature with the progress of extraction under sonication.

\section{Antioxidant activity}

The aqueous-ethanolic G. mollugo extracts obtained by three extraction techniques were subjected to screening for their possible antioxidant activity. Three complementary test systems, namely DPPH free radical-scavenging, total phenolic and total flavonoid compounds, were used for this purpose. Table 1 presents the $E C_{50}$ values and the amounts of total phenolic and total flavonoid compounds for all extracts, while
Figure 1 shows the percentage of DPPH reduction with increasing the extractive substances concentration without and with incubation (20 min). According to the Duncan's multiple range test, the 20 min incubation is a statistically significant factor at the significance level of 95\% only for the ultrasonic extraction.

Table 1 show that all the investigated extracts have high phenolic and flavonoid contents, confirming an earlier observation that plant extracts with a high phenolics content also contain a high flavonoids content [32]. In general, extracts with a high antioxidant activity have a high phenolic content [27]. Total phenolics and flavonoids were present at the highest concentrations in extracts obtained by the reflux extraction, while their lowest concentrations were found in the extracts obtained by the maceration (Table 1 ). The results of Duncan's multiple range test for the contents of total phenols and total flavonoids were the same. At the significance level of $95 \%$, both contents achieved by the reflux extraction were significantly higher than those reached by the maceration and ultrasonic extraction, and both contents achieved by the ultrasonic extraction were significantly higher than that obtained by the maceration. The extract obtained by the reflux extraction had higher amount of phenolics compound than those obtained by the maceration and ultrasonic extraction by 29.1 and $17.9 \%$, respectively. Also, extract obtained by extraction with reflux had by $13.2 \%$ and $15.4 \%$ higher content of flavonoids than those obtained by maceration and ultrasonic extraction, respectively. This was explained by oxidation and degradation of some bioactive compounds in the interaction with highly reactive hydroxyl radicals formed during sonication of the aqueous solution [18]. Such composition of the extracts is probably due to the increased solubility of phenols and flavonoids in the extracting solvent at higher extraction temperatures.

As expected, the DPPH antioxidant activity of aqueous-ethanolic G. mollugo extracts increased with the increase of the concentration of extracts in the range from 0.005 to $0.30 \mathrm{mg} / \mathrm{ml}$ independently of the extraction technique applied (Figure 1). The DPPH antioxidant activities of the most concentrated extracts $(0.30$ $\mathrm{mg} / \mathrm{ml}$ ) obtained by maceration, reflux and ultrasonic extractions were 98.9, 99.6 and 91.1\% (with 20 min

Table 1. Extraction yield, antioxidant activity, content of total phenolics and total flavonoids of aqueous-ethanolic G. mollugo extracts obtained by different extraction techniques; The values $(n=3)$ that have no common superscript are significantly different at the 95\% confidence level according to Duncan's multiple range test

\begin{tabular}{|c|c|c|c|c|c|}
\hline \multirow[b]{2}{*}{ Extraction technique } & \multirow{2}{*}{$\begin{array}{l}\text { Yield of extractive } \\
\text { substances, mass\% }\end{array}$} & \multicolumn{2}{|c|}{$E C_{50}, \mathrm{mg} / \mathrm{ml}$} & \multirow{2}{*}{$\begin{array}{c}\text { Total phenolics } \\
\text { content, mg GAE/g } \\
\text { dry extract }\end{array}$} & \multirow{2}{*}{$\begin{array}{c}\text { Total flavonoids } \\
\text { content, mg RE/g } \\
\text { dry extract }\end{array}$} \\
\hline & & $\begin{array}{c}\text { Without } \\
\text { incubation }\end{array}$ & $\begin{array}{l}\text { With } 20 \mathrm{~min} \\
\text { incubation }\end{array}$ & & \\
\hline Maceration & $16.80 \pm 0.46^{a, b}$ & $0.055 \pm 0.003^{c}$ & $0.051 \pm 0.002^{c, f}$ & $243.30 \pm 2.50$ & $65.97 \pm 0.82$ \\
\hline Reflux extraction & $17.60 \pm 0.36^{a}$ & $0.046 \pm 0.004^{d}$ & $0.045 \pm 0.003^{d}$ & $295.83 \pm 0.95$ & $76.03 \pm 1.12$ \\
\hline Ultrasonic extraction & $17.05 \pm 0.25^{b}$ & $0.073 \pm 0.003^{e, f}$ & $0.062 \pm 0.002^{\mathrm{e}}$ & $209.33 \pm 0.80$ & $64.33 \pm 0.78$ \\
\hline
\end{tabular}


incubation), and 97.9, 98.9 and $89.1 \%$ (without incubation), respectively. The lowest degree of DPPH radical scavenging was achieved for the extract obtained by ultrasonic extraction. This could be attributed to the degradation of the bioactive components, responsible for the antioxidant activity, under sonication [33]. The obtained results show that the incubation time had no influence on the DPPH radical scavenging. The $\mathrm{EC}_{50}$ value was the highest for the extract obtained by ultrasonic extraction.
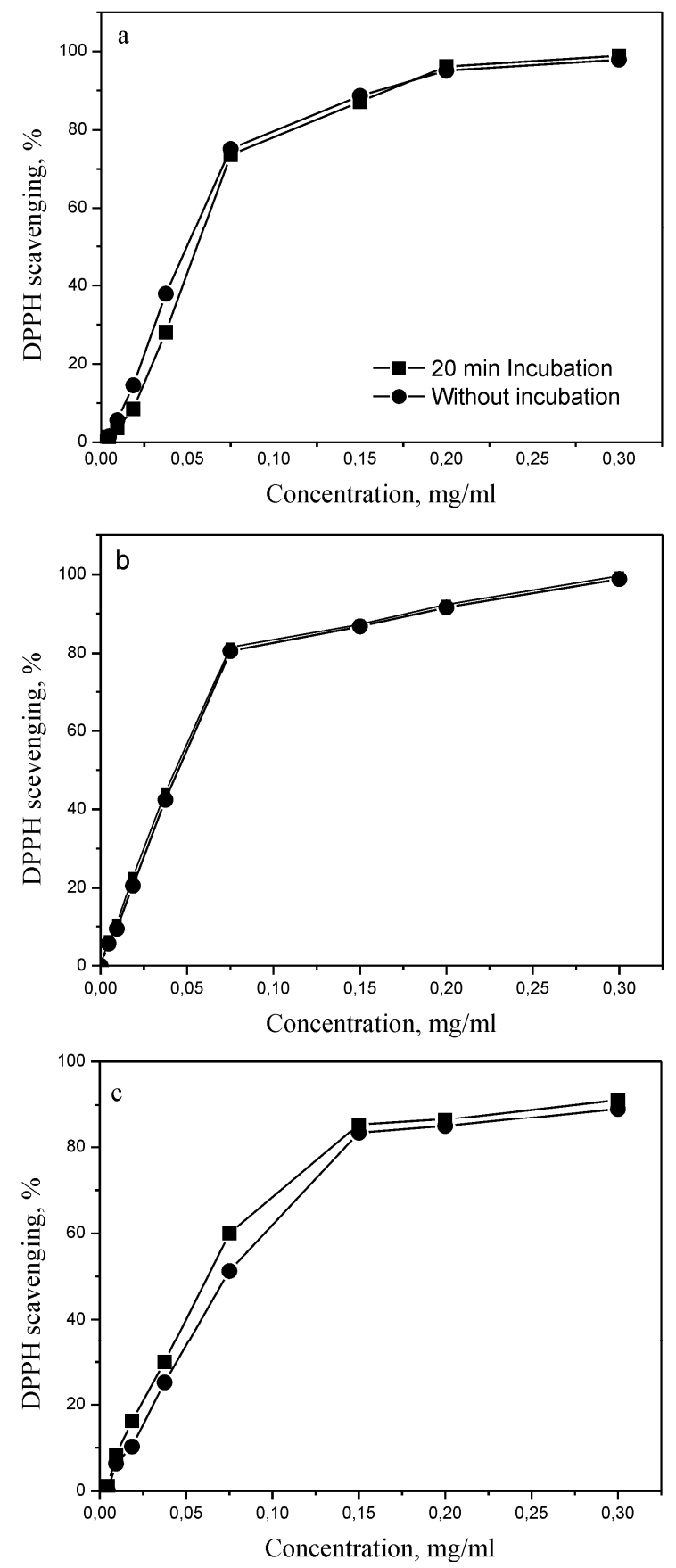

Figure 1. DPPH value versus concentration of extract without and with incubation (20 $\mathrm{min}):$ a) maceration, b) reflux extraction and c) ultrasonic extraction.
The $E C_{50}$ value is a parameter widely used to measure the free radical scavenging activity. The extract obtained by the reflux extraction had the lowest $E C_{50}$ value, meaning that it showed the best antioxidant activity. The results of Duncan's multiple range test showed that sonication had a statistically more significant impact on the $E C_{50}$ value at the significance level of $95 \%$, compared to the maceration and reflux extraction. Also, it was shown that at the significance level of $95 \%$ the maceration was statistically more significant for the $E C_{50}$ value than the reflux extraction.

\section{CONCLUSIONS}

A comparative study of antioxidant activity, content of total phenolic and total flavonoid compounds of the aqueous-ethanolic extracts obtained from aerial parts G. mollugo by extraction in the presence (ultrasonic extraction) and the absence (maceration and reflux extraction) of ultrasound was carried out. The yields of extractive substances, total phenolics and total flavonoids, as well as the antioxidant activity of the extracts depend on the extraction technique used. The use of ultrasound reduces both the extraction time due to the positive impact of cavitation events and the antioxidant activity of the extracts due to the decrease of total phenolics and total flavonoids yields. The highest yield of extractive substances, content of total phenolic and total flavonoid compounds were found in the extract obtained by extraction with reflux. This extract showed the best antioxidant activity. The extract obtained by the reflux extraction having the highest amounts of extractive substances, as well as phenolic and flavonoids compounds showed the best antioxidant activity. The present investigation suggests that aqueous-ethanolic extracts of $G$. mollugo aerial parts are a potential source of natural antioxidants. However, more work should be done to determine individual phenolic compounds of the G. mollugo extracts, which are responsible for the antioxidant activity.

\section{Acknowledgments}

This study is a part of the project TR-34012 entitled "Plant and synthetic bioactive products of new generation", financially supported by the Ministry of Education, Science and Technological Development of the Republic of Serbia.

\section{REFERENCES}

[1] K. Haila, Effects of carotenoids and carotenoid-tocopherol interaction on lipid oxidation in vitro. Academic dissertation, University of Helsinki, Department of Applied Chemistry and Microbiology, 1999.

[2] Z. Spacil, L. Novakova, P. Solich, Analysis of phenolic compounds by high performance liquid chromatography 
and ultra performance liquid chromatography, Talanta 76 (2008) 189-199.

[3] Y. Lu, L.Y. Foo, Antioxidant activities of polyphenols from sage (Salvia officinalis), Food Chem. 75 (2001) 197 202.

[4] L.R. Fukumoto, G. Mazza, Assessing, antioxidant and prooxidant activities of phenolic compounds, J. Agric. Food Chem. 48 (2000) 3597-3604.

[5] D.D. Kitts, An evaluation of the multiple effects of the antioxidant vitamins, Trends Food Sci. Technol. 8 (1997) 198-203.

[6] J. Wall, Antioxidants in prevention of reperfusion damage of vascular endothelium, Pharmacology 1 (2000) 67-71.

[7] R. Aquino, S. Morelli, A. Tomaino, M. Pellegrino, A. Saija, L. Grumetto, C. Puglija, D. Ventura, F. Bonina, Antioxidant and photoprotective activity of a crude extract of Culcitium reflexum H.B.K. Leaves and their major flavonoids, J. Ethnopharmacol. 79 (2002) 183-191.

[8] N. Ito, S. Fukushima, H. Tsuda, Carcinogenecity and modification of the carcinogenic response by $\mathrm{BHA}, \mathrm{BHT}$ and other antioxidants, Crit. Rev. Toxicol. 15 (1985) 109-115 .

[9] J.D. Mladenović, P.Z. Mašković, R.M. Pavlović, B.C. Radovanović, G. Aćamović-Đoković, M.S. Cvijović, Antioxidant activity of ultrasonic extracts of leek Allium porrum L., Hem. Ind. 65 (2011) 473-477 (in Serbian).

[10] N. Lakić, N. Mimica-Dukić, J. Isak, B. Božin, Antioxidant properties of Galium verum L. (Rubiaceae) extracts, Cent. Eur. J. Biol. 5 (2010) 331-337.

[11] P. Milić, D. Bekrić, S. Milić, K. Rajković, A study of the extraction kinetics of the minerals from the white lady's bedstraw (Galium mollugo L.) by using an artificial neural network, Hem. Ind. 65 (2011) 313-321.

[12] N. Bisset, M Wichtl, Herbal Drugs and Phytopharmaceuticals, CRC Press, Boca Raton, FL, 2001.

[13] J. Tucakov, Healing by Plants, Rad, Belgrade, 2006 (in Serbian).

[14] T. Il'ina, A. Kovaleva, O. Goryachaya, Essential oil from Galium verum flowers, Chem. Nat. Compd. 45 (2009) 587-588.

[15] M. Tamas, D. Stana, S. Timis, Comparative phytochemical research of Galium verum and G. mollugo L., Not. Bot. Hort. Agrobot. Cluj. 34 (2006) 18-20.

[16] D. Banthorpe, J. White, Novel anthraquinones from undifferentiated cell cultures of Galium verum. Phytochemistry 38 (1995) 107-111.

[17] L. Rafaëll, S. Héron, W. Nowik, A. Tchapla, Optimisation of ESI-MS detection for the HPLC of anthraquinone dyes. Dyes Pigments 77 (2008) 191-203.

[18] M. Vinatoru, M. Toma, T.J. Mason, Ultrasonically assisted extraction of bioactive principles from plants and their constituents. In: Advances in Sonochemistry, J.T. Mason (Ed.), JAI Press, Stamford, CA, 1999.

[19] L. Paniwyk, E. Beaufoy, J.P. Lorimer, T.J. Mason, The extraction of rutin from flower buds of Sophora Japonica. Ultrason. Sonochem. 8 (2001) 299-301.
[20] M. Romdhane, C. Gourdon, Investigation in solid-liquid extraction: influence of ultrasound, Chem. Eng. J. 87 (2002) 11-19.

[21] M. Toma, M. Vinatoru, L. Paniwnyk, T.J. Mason, Investigation of the effects of ultrasound on vegetal tissues during solvent extraction, Ultrason. Sonochem. 8 (2001) 137-142.

[22] L. Cseke, A. Kirakosyan, P. Kaufman, S. Warber, J. Duke, H. Brielmann, Natural Products from Plants, CRC Press Taylor \& Francis Group, Boca Raton, FL, 2006.

[23] D.T. Veličković, D.M. Milenović, M.S. Ristić, V.B. Veljković, Kinetics of ultrasonic extraction of extractive substances from garden (Salvia officinalis L.) and glutinous (Salvia glutinosa L.) sage, Ulltrason. Sonochem. 13 (2006) 150-156.

[24] D.T. Veličković, D.M. Milenović, M.S. Ristić, V.B. Veljković, Ultrasonic extraction of waste solid residues from the Salvia sp. essential oil hydrodistillation, Biochem. Eng. J. 42 (2008) 97-104.

[25] L.-C. Lu, Y.-W.C. Chen, C.-C. Chou, Antibacterial and DPPH Free Radical-scavenging Activities of the Ethanol Extract of propolis Collected in Taiwan. J. Food Drug. Anal. 11 (2003) 277-282.

[26] W.C. Choi, C.S. Kim, S.S. Hwang, K.B. Choi, J.H. Ahn, Y.M. Lee,. H.S. Park, K.S. Kim, Y.M. Lee, Antioxidant activity and free radical scavenging capacity between Korean medicinal plants and flavonoids by assay-guided comparison, Plant. Sci. 163 (2002) 1161-1168.

[27] Lj. Stanojević, M. Stanković, V. Nikolić, Lj. Nikolić, Antioxidative and antimicrobial activities of Hieracium pilosella L. extracts, J. Serb. Chem. Soc. 73 (2008) 531-540.

[28] Lj. Stanojević, M. Stanković, V. Nikolić, Lj. Nikolić, D. Ristić, J. Čanadanovic-Brunet, V. Tumbas, Antioxidant Activity and Total Phenolic and Flavonoid Contents of Hieracium pilosella L. Extracts, Sensors 9 (2009) 5702-5714 .

[29] V.L. Singleton, R. Orthofer, R.M. Lamuela-Raventos, Analysis of total phenols and other oxidation substrates and antioxidants by means of Folin-Ciocalteu reagent. Meth. Enzymol. 299 (1999) 152-178.

[30] J.-Y. Lin, C.-Y. Tang, Determination of total phenolic and flavonoid contents in selected fruits and vegetables, as well as their stimulatory effects on mouse splenocyte proliferation, Food Chem. 101 (2007) 140-147.

[31] M. Vinatoru, M. Toma, O. Radu, P.I. Filip, D. Lazurca, T.J. Mason, The use of ultrasound for the extraction of bioactive principles from plant materials, Ultrason. Sonochem. 4 (1997) 135-139.

[32] P. Maisuthisakul, M. Suttajit, R. Pongsawatmanit, Assessment of phenolic content and free radical-scavenging capacity of some Thai indigenous plants, Food Chem. 100 (2007) 1409-1418.

[33] M. Vinatoru, An overview of the ultrasonically assisted extraction of bioactive principles from herbs, Ultrason. Sonochem. 8 (2001) 303-313. 


\section{IZVOD}

\section{ANTIOKSIDATIVNA AKTIVNOST EKSTRAKATA Galium mollugo L. DOBIJENIH RAZLIČITIM TEHNIKAMA EKSTRAKCIJE}

Petar S. Milić ${ }^{1}$, Ljiljana P. Stanojević ${ }^{2}$, Katarina M. Rajković ${ }^{1}$, Slavica M. Milić ${ }^{3}$, Vesna D. Nikolić ${ }^{2}$, Ljubiša B. Nikolić $^{2}$, Vlada B. Veljković

${ }^{1}$ Visoka hemijsko-tehnološka škola strukovnih studija, Kruševac, Srbija

${ }^{2}$ Univerzitet u Nišu, Tehnološki fakultet, Leskovac, Srbija

${ }^{3}$ Apoteka „Sveti Nikola", Leskovac, Srbija

(Naučni rad)

$\mathrm{U}$ radu je određen prinos ekstraktivnih supstanci, antioksidativna aktivnost, sadržaj ukupnih fenola i flavonoida u vodeno-etanolnim ekstraktima dobijenim iz nadzemnih delova Galium mollugo L., primenom različitih tehnika ekstrakcije (maceracija, refluks i ultrazvučna ekstrakcija). Antioksidativna aktivnost ekstrakata je ispitivana primenom DPPH testa. Sadržaj ukupnih fenola određen je primenom Folin-Ciocalteu metode, dok je sadržaj ukupnih flavonoida određen spektrofotometrijskom metodom sa aluminijum-hloridom. Dankanov test multipnog opsega korišćen je za utvrđivanje razlika u prinosu ekstraktivnih supstanci, antioksidativnoj aktivnosti, sadržaju ukupnih fenola i ukupnih flavonoida u ekstraktima dobijenim različitim tehnikama ekstrakcije. Dobijeni rezultati pokazuju da prinos ekstraktivnih supstanci, sadržaj ukupnih fenola i flavonoida, kao i antioksidativna aktivnost zavise od primenjene tehnike ekstrakcije. Ekstrakcijom uz refluks dobija se veći prinos ekstraktivnih supstanci, ukupnih fenola i flavonoida, a ekstrakt pokazuje bolju antioksidativnu aktivnost od ekstrakata dobijenih maceracijom i ultrazvučnom ekstrakcijom.

Ključne reči: Antioksidativna aktivnost • Dankanov test - Tehnike ekstrakcije • Galium mollugo L. • Ukupni fenoli • Ukupni flavonoidi 